\title{
SDS-PAGE and Western blot of urinary proteins in dogs with leishmaniasis
}

\author{
Concepción ZARAGOZA ${ }^{\mathrm{a} *}$, Rafael BARRERA ${ }^{\mathrm{a}}$, Francisco CENTENO ${ }^{\mathrm{b}}$, \\ Jose A. TAPIA ${ }^{\mathrm{c}}$, Esther DURÁN ${ }^{\mathrm{a}}$, Marta GONZÁLEZ ${ }^{\mathrm{d}}$, M. Cinta MAÑÉ ${ }^{\mathrm{a}}$ \\ a Departamento de Medicina y Sanidad Animal, Facultad de Veterinaria, Universidad de Extremadura, \\ Avda. Universidad s/n, 10004 Cáceres, Spain \\ b Departamento de Bioquímica, Biología Molecular y Genética, Facultad de Veterinaria, \\ Universidad de Extremadura, Avda Universidad s/n, 10004 Cáceres, Spain \\ ${ }^{c}$ Digestive Diseases Branch, NIDDK/NIH, Bethesda, MD, USA \\ d Departamento de Patología Animal II, Facultad de Veterinaria, Universidad Complutense de Madrid, \\ Madrid, Spain
}

(Received 21 February 2002; accepted 23 September 2002)

\begin{abstract}
Canine leishmaniasis is an endemic disease in the Mediterranean area caused by the protozoan Leishmania infantum, which usually produces renal failure. Sodium dodecyl sulphate polyacrylamide gel electrophoresis and Western blot using antibodies to $\operatorname{IgG}$ and $\operatorname{IgA}$ from dogs were carried out in the urine of 22 dogs with leishmaniasis diagnosed by ELISA and confirmed by PCR, and 20 healthy dogs. The results were compared to renal function laboratory tests and to those from a histopathological study of the kidneys from sick animals that died naturally or were euthanized. Five different bands with molecular weights ranging from 10 to $110 \mathrm{kDa}$ were obtained from the electrophoresis of the urine of healthy dogs. $33.5 \%$ of total proteins corresponded to low molecular weight proteins and the other proteins had middle and high molecular weights. However, in the group with leishmaniasis, a maximum of 11 different bands with molecular weights ranging from $10 \mathrm{kDa}$ to $150 \mathrm{kDa}$ were displayed in the electrophoresis of the urine. The urine electrophoretic pattern in the sick dogs was classified as mixed (proteins with high and low molecular weights) because low molecular weight proteins made up 57.9\% and the rest of the proteins had middle and high molecular weights. In Western blot, none of the healthy dogs showed excretion of IgG and/or $\operatorname{IgA}$, whereas IgG and IgA were detected in the Western blot of urine of 68\% and 55\% respectively of dogs with leishmaniasis. The results obtained in the leishmaniasis group agreed with glomerular and tubular damage, which were confirmed by the histopathological findings.
\end{abstract}

leishmaniasis / proteinuria / dog / SDS-PAGE / Western blot

\section{INTRODUCTION}

Canine leishmaniasis is a major zoonosis parasitic disease, enzootic in the Medi- terranean area, caused by the intracellular protozoan Leishmania infantum [19, 32]. The dog is the main reservoir host of the parasite. Liver damage is not common in

\footnotetext{
* Correspondence and reprints

Tel.: (34) 927257164; fax: (34) 927257163; e-mail: zaragoza@unex.es
} 
leishmaniasis [7] but it usually causes chronic renal failure in dogs in our working area (west of Spain), characterized by glomerulonephritis due to immune complex deposition [5], interstitial nephritis and occasionally amyloidosis $[15,31]$. The immune complexes cause a secondary inflammatory reaction [10] and the reduction in the perfusion of the peritubular capillaries leads to tubular and interstitial tissue ischemia [35]. Proteinuria is observed as a result, which can range from moderate to severe according to the evolution of the disease [8].

It has been demonstrated that the analysis of urinary proteins is very useful in the diagnosis and treatment of kidney diseases. In fact, renal lesions at different kidney locations show typical molecular weight urinary protein patterns $[3,21,37]$. Urinary proteins have been routinely studied by sodium dodecyl sulphate polyacrylamide gel electrophoresis (SDS-PAGE), because compared to other techniques, it allows the analysis of different molecular weight proteins and is less time consuming [3]. Furthermore, it is the preferred method in cases of renal pathology when low and high molecular weight proteins are present in urine samples $[33,38]$. However, the identification of proteins by electrophoresis according to their molecular sizes is limited to general conclusions about the origin of the proteinuria (glomerular, tubular or both). Conversely, SDS-PAGE followed by Western blot allows the identification of some specific urine proteins, providing more clinical and experimental information [41] about the different forms of renal alteration [16].

Because the analysis of urinary proteins may help in the characterization of the renal lesions, we determined the molecular weights of the urinary proteins from dogs with leishmaniasis, and the elimination of $\operatorname{IgG}$ and $\operatorname{IgA}$. The aim of this study was to describe the urinary electrophoretic pattern in leishmaniasis and to verify the possible correlation between this pattern and the clinical and histopathological observations.

\section{MATERIALS AND METHODS}

\subsection{Animals}

Urine samples from 20 healthy dogs used as controls, and from 22 naturally infected dogs with leishmaniasis were studied. The leishmaniasis group included animals of different breeds, sex and age but all were adults taken to the Veterinary Teaching Hospital at Extremadura University (Spain) showing symptomatology compatible with this infection [18]. History, physical examination, and blood and urine tests were carried out, as well as radiological and/or sonographic studies, if necessary, in order to diagnose the renal disease. Leishmaniasis was diagnosed by enzyme-linked immunosorbent assay (ELISA) in serum and confirmed by polymerase chain reaction (PCR) in whole blood. Furthermore, differential diagnosis with infections that cause the same kidney lesions in our working area, such as ehrlichiosis and babesiosis, was performed using ELISA [1, 24] and PCR [2, 13]. The same protocol as that used on leishmaniasis infected dogs was applied to the control group dogs to confirm the absence of this, or any other disease that could affect the results of this study.

\subsection{Enzyme-linked immunosorbent assay (ELISA)}

For the initial diagnosis of leishmaniasis, the ELISA procedure described by Nieto et al. [27] was applied. Briefly, the antigen used for the determinations was obtained from late-log phase cultures of L. infantum promastigotes (M/CAN/ES/ 88/CHUMI, LEM 2002). The ELISA plates (96 wells; Inotech, Dottikon, Switzerland) were coated with the antigen overnight at $4{ }^{\circ} \mathrm{C}(100 \mu \mathrm{L}$ per well of a solution of $8 \mu \mathrm{g} / \mathrm{mL}$ ) and three washes with PBS$0.05 \%$ Tween 20 were performed. The plates were blocked with $5 \%$ non-fat dried milk for $30 \mathrm{~min}$ at $37{ }^{\circ} \mathrm{C}$ and washed three times. Then the plates were incubated for 
30 min at $37{ }^{\circ} \mathrm{C}$ with the sera at a dilution of 1/400 in PBS-Tween 20 and washed three times with PBS. Later, they were incubated with $100 \mu \mathrm{L}$ per well of rabbit anti-dog IgG-peroxidase conjugate (Sigma-Aldrich, Inc., St. Louis, MO, USA) diluted in PBS-Tween 20 at $1 / 8000$ for $30 \mathrm{~min}$ at $37{ }^{\circ} \mathrm{C}$. The plates were washed and the enzymatic reaction was developed with $o$-phenyldiamine (SigmaAldrich, Inc., St. Louis, MO, USA). The reaction was stopped $30 \mathrm{~min}$ later by addition of $50 \mu \mathrm{L}$ of $3 \mathrm{~N} \mathrm{H}_{2} \mathrm{SO}_{4}$ to each well. Finally, absorbance values were read at $490 \mathrm{~nm}$ in an automatic micro-ELISA reader (Merck, Darmstadt, Germany).

\subsection{DNA extraction and polymerase chain reaction $(\mathbf{P C R})$}

DNA was extracted and standardized from each sample in this study using the Blood Spin kit (Mobio, Solana Beach, CA, USA). For the detection of genomic Leishmania DNA, the PCR procedure described by Piarroux et al. [30] was used with minor modifications. This procedure permitted the identification of a highly repetitive $100 \mathrm{bp}$ sequence of $L$. infantum. Briefly, the final volume for each reaction was $50 \mu \mathrm{L}$ with reagent concentrations of $0.250 \mu \mathrm{M}$ for each primer, $10 \mathrm{mM}$ Tris$\mathrm{HCl} \mathrm{pH} 8.3,50 \mathrm{mM} \mathrm{KCl}, 1.5 \mathrm{mM} \mathrm{MgCl}{ }_{2}$, $250 \mu \mathrm{M}$ for each deoxynucleoside triphosphate (dNTP: dATP, dCTP, dTTP, dGTP), $1.5 \mathrm{U}$ of $T a q$ DNA polymerase (AmpliTaq Gold, Applied Biosystems, Foster City, CA, USA), and $2 \mu \mathrm{L}$ of DNA extract of the corresponding sample. Amplifications were performed over 40 cycles in a programmable thermal cycler (Gene Amp PCR System 2400, Perkin-Elmer, Foster City, CA, USA) using the following conditions: denaturing at $94{ }^{\circ} \mathrm{C}$ (first cycle $12 \mathrm{~min}$, all further cycles $30 \mathrm{~s}$ ), annealing at $60{ }^{\circ} \mathrm{C}$ (30 s), and extension at $72{ }^{\circ} \mathrm{C}(30 \mathrm{~s})$, followed by a final extension period $\left(72{ }^{\circ} \mathrm{C}\right.$, $10 \mathrm{~min}$ ). PCR products, and negative and positive controls, were assessed by electro- phoresis of $6 \mu \mathrm{L}$ of each product in a $2 \%$ agarose gel containing ethidium bromide.

\subsection{Blood and urine tests}

Hematology (leukocytes, erythrocytes and platelet counts, packed cell volume, mean cell volume - MCV, mean cell hemoglobin concentration - MCHC, differential count of leukocytes) and serum biochemistry (blood urea nitrogen, creatinine, calcium, phosphorus, cholesterol, total proteins, albumin) were performed using previously standardized techniques [9]. Urine was obtained by cystocentesis. Part of the urine was sent for culture to exclude urinary tract infection and the rest was centrifuged for $5 \mathrm{~min}$ at $20 \mathrm{~g}$. The sediment was examined, and one part of the supernatant was frozen at $-80{ }^{\circ} \mathrm{C}$ until the electrophoresis and Western blot were carried out. The rest of the supernatant was immediately used to determine the protein concentration by the Lowry method [20], and that of creatinine, to calculate the urine protein/creatinine ratio (U P/C) [22].

\subsection{SDS-PAGE}

Urine proteins were fractionated by SDS-PAGE using $10.4 \%$ polyacrylamide gels following the procedure described by Laemmli [17]. SDS-PAGE was performed with a Mini Protean II Cell system (BioRad, Hercules, CA, USA). In each electrophoresis a molecular weight marker was included (alpha-lactalbumin: $14.4 \mathrm{kDa}$, inhibitor of trypsin: $20.1 \mathrm{kDa}$; carbonic anhydrase: $30 \mathrm{kDa}$; ovalbumin: $43 \mathrm{kDa}$; albumin: $67 \mathrm{kDa}$ and phosphorylase $\mathrm{b}$ : $94 \mathrm{kDa}$; Amersham-Pharmacia Biotech, Piscataway, NJ, USA), along with 1 urine sample from a healthy dog and 8 from infected dogs with $L$. infantum. The amount of proteins loaded was $5 \mu \mathrm{g}$ per sample. Gels were stained using the Coomassie method and were analyzed in a gel scanner densitometer (Ultroscan XL, Pharmacia LKB Biotechnology Inc., Piscataway, NJ, USA). The graphic 
representations and molecular weights of the bands for each lane were obtained using the Ultroscan GSX software (Pharmacia LKB Biotechnology, Inc., Piscataway, NJ, USA).

\subsection{Western blot}

Western blot was performed as described previously [25, 40]. In brief, after separation by SDS-PAGE the proteins were transferred to nitrocellulose membranes. The membranes were blocked at $25{ }^{\circ} \mathrm{C}$ for $30 \mathrm{~min}$ using a blocking solution $(10 \%$ non-fat dried milk in a PBSTween 20 solution: $0.08 \mathrm{M} \mathrm{K} \mathrm{K}_{2} \mathrm{HPO}_{4}$, $0.02 \mathrm{M} \mathrm{KH}_{2} \mathrm{PO}_{4}, 0.10 \mathrm{M} \mathrm{NaCl}$ and $0.2 \%$ (v/v) Tween 20), washed twice for $1 \mathrm{~min}$ with PBS-Tween 20, and incubated for $1 \mathrm{~h}$ at $25{ }^{\circ} \mathrm{C}$ with $0.24 \mu \mathrm{g} / \mathrm{mL}$ of rabbit anti$\mathrm{IgG}$ polyclonal antibody or $0.15 \mu \mathrm{g} / \mathrm{mL}$ of rabbit anti-IgA polyclonal antibody (ICN Biomedicals, Aurora, OH, USA), which specifically recognized target immunoglobulins from dogs. After incubation with the primary antibody, membranes were washed twice for $1 \mathrm{~min}$ and once for 10 min with PBS-Tween 20, and incubated at $25^{\circ} \mathrm{C}$ for a further $30 \mathrm{~min}$ with $0.40 \mu \mathrm{g} / \mathrm{mL}$ of goat anti-rabbit IgG-horseradish peroxidase conjugate (ICN Biomedicals, Aurora, $\mathrm{OH}$, USA). Once incubated with the secondary antibody, membranes were washed once for $1 \mathrm{~min}$ and twice for $10 \mathrm{~min}$ with PBS-Tween 20. Finally, developing and detection of the bands were carried out by chemiluminiscence [42].

\subsection{Histopathological study}

Histopathological study was carried out in three dogs (Animals \#2, \#8 and \#20) that were dead or were euthanized at the owner's request. Routine necropsy was performed and the kidneys were removed. The kidneys were fixed in $4 \%$ buffered formaldehyde and $2.5 \%$ glutaraldehyde in cacodylate buffers. Samples for structural examination were routinely processed for light microscopy and embedded in paraf- fin. Sections $(5 \mu \mathrm{m}$ thick) were stained with hematoxylin-eosin, and PAS. Samples for ultra-thin section analysis were postfixed in osmiun tetroxide $(1 \%)$ prior to being embedded in epoxy resin. Sections $(0.5 \mu \mathrm{m}$ thick) were stained with Toluidine blue.

\subsection{Statistical analysis}

Means and standard deviations of urine, serum and molecular weight parameters were performed using the statistical software SPSS 2000 (SPSS, Inc., Chicago, IL, USA).

\section{RESULTS}

\subsection{Diagnosis of leishmaniasis by ELISA and confirmation by PCR}

Leishmaniasis was diagnosed in a first step by ELISA in serum and confirmed by PCR in whole blood. Serum samples showing optical density values above 0.20 (cut-off value) in the ELISA assay were considered as positive. Optical density values of all the samples used as controls were below the cut-off value, with an optical density average of $0.05 \pm 0.03$. However, all dogs that showed symptomatology compatible with leishmaniasis gave optical density values higher than 0.20 with an optical density average value of $0.83 \pm$ 0.31 .

The leishmaniasis diagnosis was subsequently confirmed by PCR in whole blood. All samples from control animals were negative by gel analysis, in other words, no false negatives were obtained in $\operatorname{dogs}$ where leishmaniasis had been ruled out by ELISA. Conversely, PCR analysis allowed the constant identification of a $100 \mathrm{bp}$ sequence of $L$. infantum in all the dogs previously found to be positive by ELISA.

Moreover, to verify the absence of other diseases that could affect the results of this study we also performed, in both sick and healthy dogs, ELISA and PCR analysis to 
A
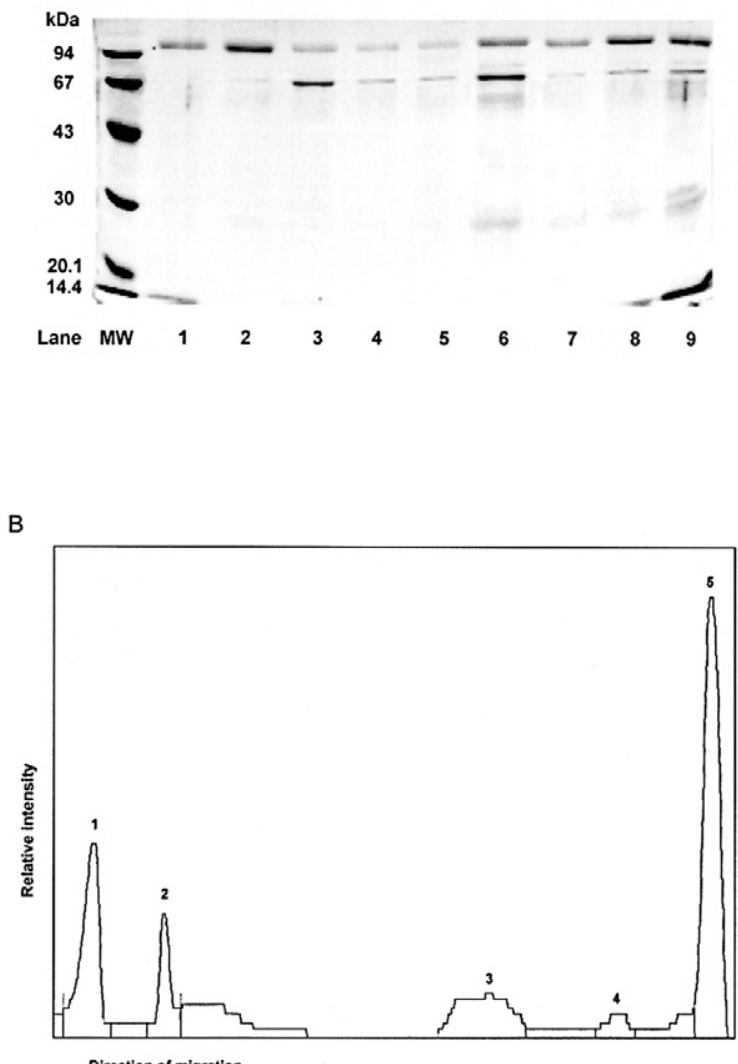

Figure 1. SDS-PAGE of urine from healthy dogs. A: Bands observed in the electrophoresis. $\mathrm{MW}=$ molecular weight marker. Lanes 1-9 = urine from healthy dogs. B: Densitometric reading of the electrophoresis from a healthy dog (5 bands).

rule out ehrlichiosis and/or babesiosis as concomitant infections. Both control and leishmaniasis dogs were negative to these diseases by both procedures.

\subsection{SDS-PAGE}

The SDS-PAGE electrophoretic patterns of urine from control dogs are shown in Figure 1. These patterns were mainly characterized by two bands observed in practically all the animals, and located in the molecular weight ranges of 100$110 \mathrm{kDa}$ and 70-80 kDa (Fig. 1, Tab. I). A third band within the range of $10-20 \mathrm{kDa}$ was observed in $50 \%$ of the animals (Fig. 1, Tab. I) and finally, in some urines two bands of low molecular weight located in
Table I. Frequencies (\%) of appearance of the bands observed in the urine of healthy dogs and dogs with leishmaniasis.

\begin{tabular}{lcc}
\hline MW (kDa) & Healthy & Leishmaniasis \\
\hline $140-150$ & - & 5 \\
$130-140$ & - & 9 \\
$110-120$ & - & 14 \\
$100-110$ & 100 & 82 \\
$80-90$ & - & 45 \\
$70-80$ & 95 & 100 \\
$50-60$ & - & 100 \\
$40-50$ & - & 100 \\
$30-40$ & 30 & 100 \\
$20-30$ & 25 & 95 \\
$10-20$ & 50 & 95 \\
\hline
\end{tabular}


A

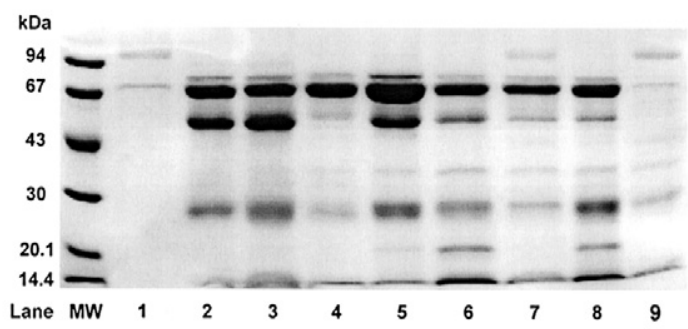

B

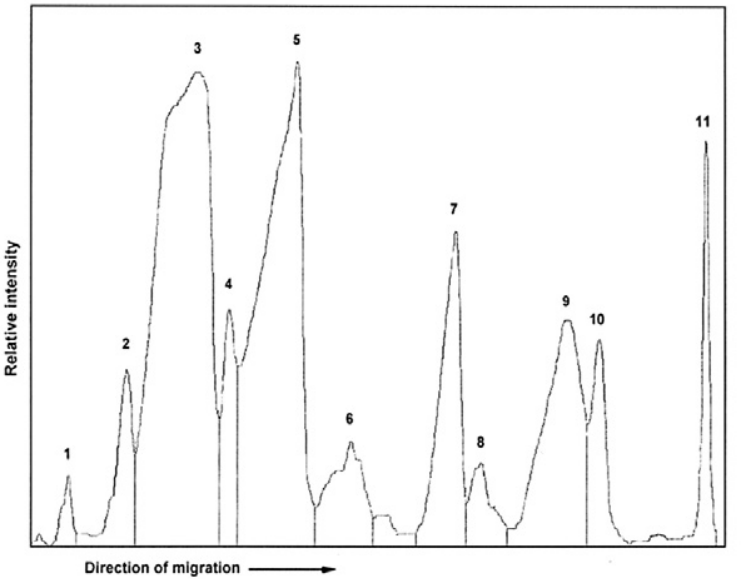

Figure 2. SDS-PAGE of urine from dogs with leishmaniasis. A: Bands observed in the electrophoresis. $\mathrm{MW}=$ molecular weight marker. Lane $1=$ urine from a healthy dog. Lanes 2-9 = urine from dogs with leishmaniasis. B: Densitometric reading of the electrophoresis from a dog with leishmaniasis (11 bands). the range of $20-40 \mathrm{kDa}$ were also observed (Fig. 1, Tab. I). 33.5\% of the urine proteins had low molecular weights, and the rest of them were of middle and high molecular weight. These electrophoretic results correlated well with the low average $\mathrm{U} \mathrm{P} / \mathrm{C}$ ratio $(0.5 \pm 0.2)$ found in the urine.

Proteinuria in the group of dogs with leishmaniasis was greater than in the control group as indicated by its average $\mathrm{U}$ $\mathrm{P} / \mathrm{C}$ ratio $(5.4 \pm 6.9)$. This fact was clearly shown in the urine electrophoretic patterns (Fig. 2). Eleven different bands were obtained (Fig. 2B) compared to a maximum of five bands obtained in the urine of healthy dogs (Fig. 1B). Notably, bands in the range of $30-80 \mathrm{kDa}$ were observed in the 22 dogs with leishmaniasis (Fig. 2A, Tab. II). Bands in the ranges of $10-20 \mathrm{kDa}$
Table II. Mean \pm standard deviation (SD) from molecular weight (MW) of the bands that appeared in the urine from dogs with leishmaniasis except the $140-150 \mathrm{kDa}$ range, in which only one band was observed in one dog.

\begin{tabular}{lcc}
\hline $\begin{array}{l}\text { MW (kDa) } \\
\text { Ranges }\end{array}$ & $\begin{array}{c}\text { N. dogs } \\
\text { N }=22\end{array}$ & $\begin{array}{c}\text { MW }(\mathrm{kDa}) \\
\text { Mean } \pm \text { SD }\end{array}$ \\
\hline $140-150$ & 1 & 143.0 \\
$130-140$ & 2 & $132.0 \pm 0.0$ \\
$120-130$ & 0 & - \\
$110-120$ & 3 & $113.6 \pm 1.5$ \\
$* 100-110$ & 18 & $102.0 \pm 4.4$ \\
$90-100$ & 0 & - \\
$80-90$ & 10 & $83.6 \pm 1.3$ \\
$* 70-80$ & 22 & $71.3 \pm 5.3$ \\
$60-70$ & 0 & - \\
$50-60$ & 22 & $54.4 \pm 1.7$ \\
$40-50$ & 22 & $43.8 \pm 1.5$ \\
$* 30-40$ & 22 & $35.1 \pm 1.1$ \\
$* 20-30$ & 21 & $26.1 \pm 1.6$ \\
$* 10-20$ & 21 & $16.0 \pm 1.5$ \\
\hline
\end{tabular}

*Bands also observed in healthy dogs. 
A

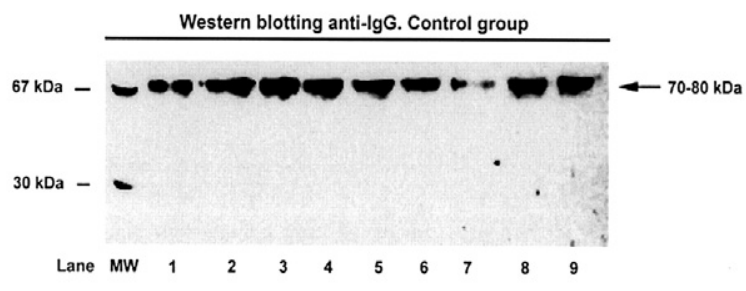

B

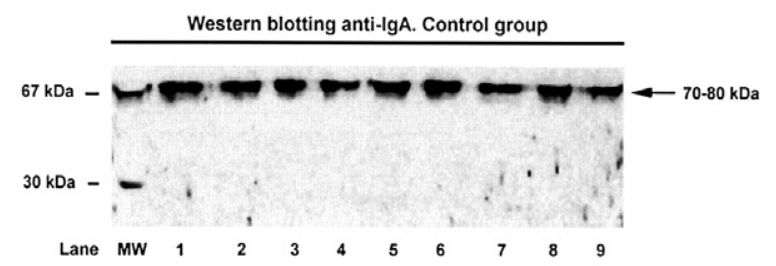

Figure 3. Western blot of urine in the healthy dogs. $\mathrm{MW}=$ molecular weight marker. Lanes 1-9 = urine from healthy dogs. Non-specific signs of the antibodies in the molecular weight marker $(67 \mathrm{kDa}$ and $30 \mathrm{kDa}$ ) and in the range of 70 80 kDa (lanes 1-9). A: Bands observed when using anti-IgG. B: Bands observed when using anti-IgA. and 20-30 kDa were also observed, but only in 21 of them (Fig. 2A, Tab. II). Although the appearance of bands in the high molecular weight range $(80-150 \mathrm{kDa})$ decreased significantly (Tab. I), the band located at 100-110 kDa was observed in a large number of dogs (Tab. II), and new bands in the ranges of $110-120 \mathrm{kDa}$ and $130-150 \mathrm{kDa}$ were visualized in six animals (Tab. II). Finally, low molecular weight proteins represented $57.9 \%$ in the group with leishmaniasis and the rest of the proteins had middle and high molecular weights.

\subsection{Western blot}

In order to test the loss of immunoglobulins in urine we carried out a Western blot assay using commercially available antibodies to dog IgG or to dog IgA. Both IgG and IgA antibodies non-specifically recognized two proteins of the molecular weight marker, i.e. carbonic anhydrase (30 kDa) and albumin $(67 \mathrm{kDa})$, and one protein of about $70 \mathrm{kDa}$ present in the samples from healthy and sick dogs (Figs. 3 and 4).
With respect to the specific signals, none of the healthy dogs showed excretion of $\operatorname{IgG}$ and/or IgA according to the Western blot results (Fig. 3). Conversely, we found two very intense bands in 15 $(68 \%)$ of the dogs with leishmaniasis when an anti-IgG antibody was used (Fig. 4A, Tab. III). Moreover, these animals also showed the largest number of symptoms recorded in the sick dog group (Tab. III). The high molecular weight band (43.8 \pm $1.5 \mathrm{kDa}$ ) might correspond to IgG heavy chains (Fig. 4A), whose molecular size has been estimated around $45 \mathrm{kDa}$ [29]. The second band, which presented a lower molecular weight $(26.1 \pm 1.6 \mathrm{kDa})$, might correspond to light chains of IgG (Fig. 4A) that has been described to possess a molecular weight around $25 \mathrm{kDa}$ [29]. Finally, we found that the band related with the heavy chain of immunoglobulins was detected in three dogs without its complementary light chain (Fig. 4A), so it could correspond to either a non-specific or a non-complete recognition of the antibody.

On the contrary, when an anti-IgA antibody was used, two bands were observed 
A

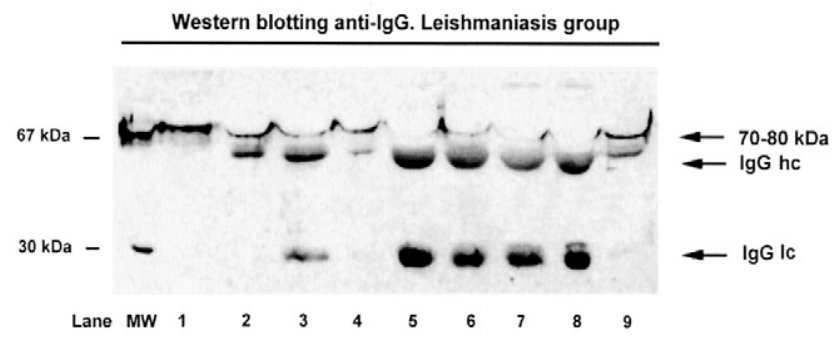

B

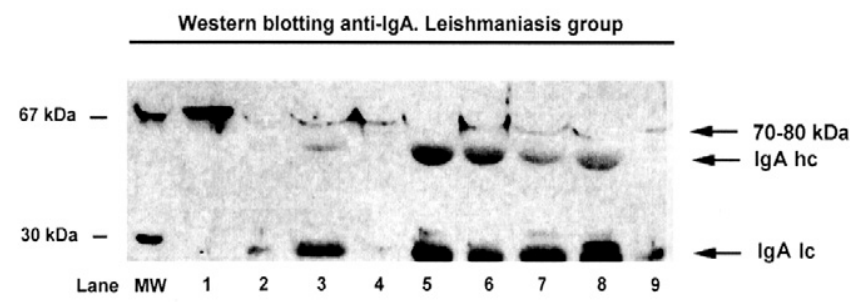

Figure 4. Western blot of urine from dogs with leishmaniasis. MW = molecular weight marker. Lane $1=$ urine from a healthy dog. Lanes $2-9=$ urine from dogs with leishmaniasis. Non-specific signs of antibodies in the molecular weight marker $(67 \mathrm{kDa}$ and $30 \mathrm{kDa})$ and in the range of 70 $80 \mathrm{kDa}$ (lane 1). A: Bands observed when using anti- $\operatorname{IgG}$. Non-specific signs in the range of 40 $50 \mathrm{kDa}$ (lanes 2, 4 and 9). Heavy (hc) and light (lc) chains of IgG are noted in lanes 3, 5, 6, 7 and 8. B: Bands observed when using anti-IgA. Non-specific signs in the range of 20-30 kDa (lanes 2 and 9). Heavy (hc) and light (lc) chains of IgA are observed in lanes 3, 5, 6, 7, and 8.

in $12(55 \%)$ of the sick dogs (Fig. 4B). Interestingly, all of them also previously showed IgG in their urine (Tab. III). The high molecular weight band (43.8 \pm $1.5 \mathrm{kDa}$ ) might correspond to heavy chains of IgA (Fig. 4B), while the other band, which was situated in the range of $20-30 \mathrm{kDa}(26.1 \pm 1.6 \mathrm{kDa})$, might relate to light chains of IgA (Fig. 4B). In two dogs only the band of molecular weight related to light chains of immunoglobulins (Fig. 4B) was observed. In a similar way to that in the IgG antibody, these signals could correspond to either a non-specific or a non-complete recognition of the antibody.
The Western blot findings suggest that leishmaniasis can cause severe renal damage, which would explain the presence of IgG and IgA in the urine of sick dogs. Histopathological studies were performed to confirm this possibility.

\subsection{Histopathological study}

Animal \#2 displayed alterations mainly in the cortical area. The proliferative changes included glomerular hypercellularity, development and proliferation of endothelial cells, and an increase in mesangial cell numbers (Fig. 5A). A cellular infiltrate made up of lymphocytes, 
Proteinuria study in canine leishmaniasis

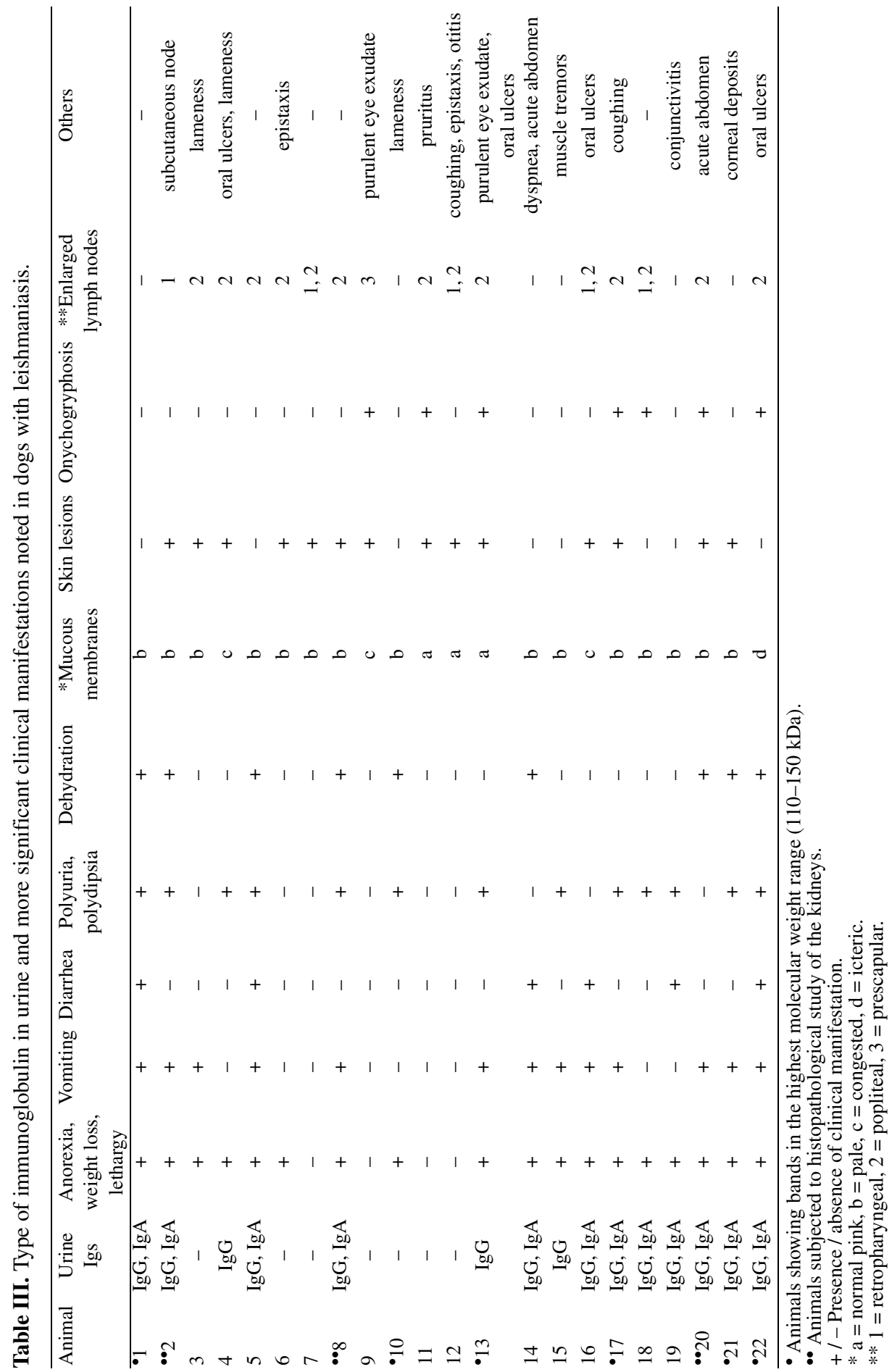


A

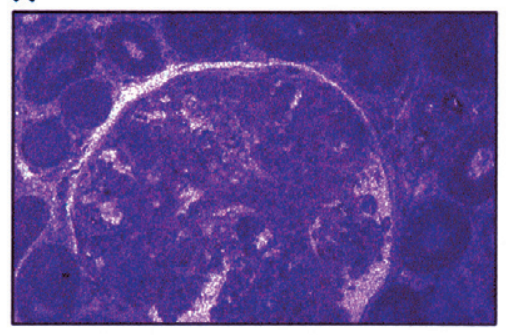

C

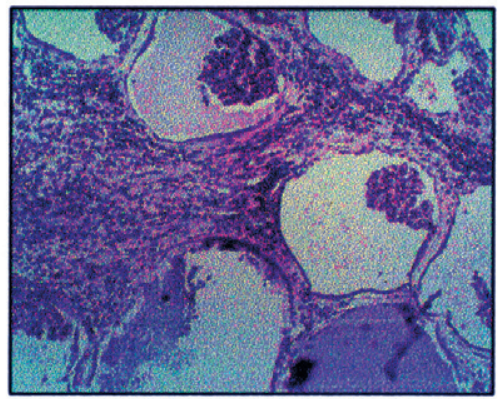

B

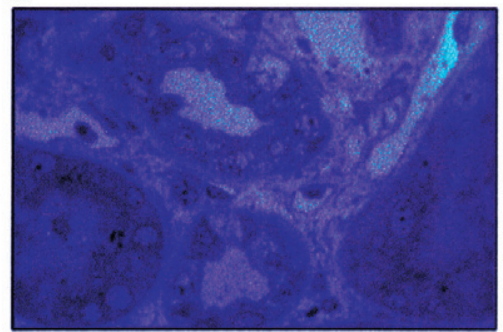

D

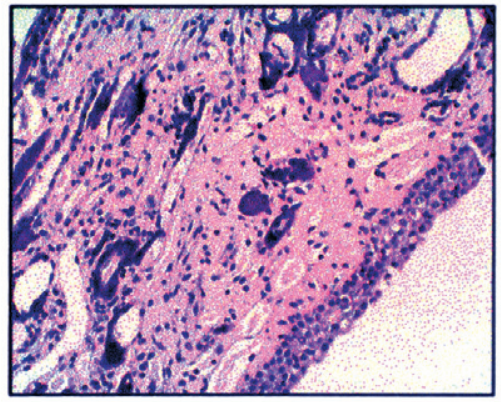

E

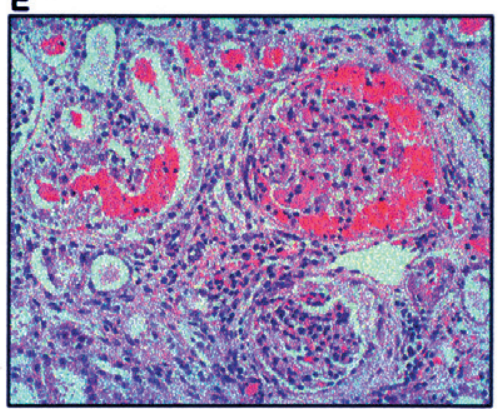

Figure 5. Histopathological study of the kidneys from three dogs with leishmaniasis. A: Mesangioproliferative glomerulonephritis in the Animal \#2 (Toluidine blue, $\times 40$ ). B: Vacuolar and hydropic degeneration of the renal tubules in Animal \#2 (Toluidine blue, $\times 100$ ). C: Cystic dilatations of renal corpuscles and tubules, glomerular atrophy, calcification of the Bowman capsule and the basal tubular membrane, and interstitial inflammatory infiltration in Animal \#8 (Hematoxylin-eosin, $\times 100$ ). D: Peritubular and tubular deposits of calcium salts and inflammatory mononuclear infiltration in Animal \#8 (Hematoxylin-eosin, $\times 200$ ). E: Periglomerular fibrosis with hyalinisation areas in the glomerulus. Lymphoplasmacytic interstitial inflammatory infiltration with a moderate amount of amber-colored pigment (hemosiderine), and presence of erythrocytes in the urinary area and in the tubular light in Animal \#20 (Hematoxylin-eosin, $\times 200$ ). 
plasmatic cells, and macrophages, was found in the renal interstitium. The tubules displayed degenerative changes that were more intense when the interstitial nephritis was greater. Vacuolar and hydropic degeneration was visible in many tubules with destruction of the tubular cells, and tubular atrophy due to compression of the mononuclear infiltrate (Fig. 5B). The lesion agreed with mesangioproliferative glomerulonephritis and interstitial nephritis.

Animal \#8 displayed many cystic dilatations at the cortical level that affected renal corpuscles and tubules. Our findings included many atrophic glomeruli and areas of calcification in the parietal face of the Bowman capsule, as well as in the basement membrane of the tubules (Fig. 5C). Calcification areas were also occasionally visualized at the medullar level, and a cellular infiltrate constituted mainly of plasmatic cells, lymphocytes and macrophages was found (Fig. 5D). The injury corresponded to a chronic sclerotic glomerulonephritis and interstitial nephritis.

Animal \#20 (Fig. 5E) presented alterations mainly in the cortical area. The kidneys showed some atrophic glomeruli and others with areas of hyalinisation and fibrosis. Most of the tubules displayed degenerative changes and some erythrocytes were observed in their lights, as well as a substance of proteic nature that was also identified in the medullar tubules. Renal interstitium showed a cellular infiltrate constituted mainly of lymphocytes and plasmatic cells with destruction and necrosis of the tubular system. The lesion agreed with chronic sclerotic glomerulonephritis and interstitial nephritis.

\section{DISCUSSION}

Using SDS-PAGE, Schultze and Jensen [34] carried out a study in the urine of clinically healthy dogs without proteinuria. In that study, they described three well-differentiated bands with molecular weights ranging from $65 \mathrm{kDa}$ to $100 \mathrm{kDa}$. Our results in the control group were in accordance with those of these authors, since the highest molecular weight proteins detected in the control dogs were restricted to the 100-110 kDa range.

The electrophoretic pattern of the urine of dogs with leishmaniasis was very homogeneous, and rather different to that of the control group. In fact, in the urine of each sick dog, several bands were found, which were absent in the control group. Specifically, bands in the ranges of $40-60 \mathrm{kDa}$, $80-90 \mathrm{kDa}$ and $110-150 \mathrm{kDa}$ were only displayed in the sick dogs (Tab. I).

In six dogs with leishmaniasis, bands in the highest molecular weight ranges described in this study $(110-150 \mathrm{kDa})$ were visualized (Tab. II). Five of these animals also showed IgG and/or IgA in the urine as well as very severe clinic manifestations (Tab. III) and laboratory abnormalities (Tab. IV). The remaining dog (Animal \#10) displayed slight hyperphosphatemia as the only apparent abnormality (Tab. IV). Therefore, excretion of higher molecular weight proteins was in accordance with Western blot findings and laboratory data.

In a previous study performed on the urine of people suffering from visceral leishmaniasis by De Colmenares et al. [6], two fractions of Leishmania antigens of $72-75 \mathrm{kDa}$ and $123 \mathrm{kDa}$ were detected by immunoblot analysis. In our study, we did not develop immunoblotting studies using specific antibodies to Leishmania proteins. Therefore, we cannot discard that some of the bands found in our electrophoretic study can be an antigenic protein of the parasite. However, none of the two antigenic proteins described by De Colmenares et al. [6] seems to be equivalent to the bands detected in this study. First, we did not detect any band with a molecular weight around $123 \mathrm{kDa}$ that could be equivalent to the higher molecular weight band previously published [6]. Second, the band found in our study in the range of $70-80 \mathrm{kDa}$ could be equivalent to 
Table IV. More significant laboratory abnormalities in the six dogs with leishmaniasis that displayed the bands of higher molecular weight by SDS-PAGE.

\begin{tabular}{lcccccc}
\hline Animal & $\begin{array}{c}* \mathrm{BUN} \\
(\mathrm{mg} / \mathrm{dL})\end{array}$ & $\begin{array}{c}\text { Creatinine } \\
(\mathrm{mg} / \mathrm{dL})\end{array}$ & $\begin{array}{c}\text { Phosphorus } \\
(\mathrm{mg} / \mathrm{dL})\end{array}$ & $\begin{array}{c}\text { Cholesterol } \\
(\mathrm{mg} / \mathrm{dL})\end{array}$ & $\begin{array}{c}\text { Albumin } \\
(\mathrm{mg} / \mathrm{dL})\end{array}$ & $* * \mathrm{U}$ P/C \\
\hline 1 & 384.0 & 7.7 & 22.5 & 372.0 & 1.8 & 2.8 \\
10 & 27.0 & 0.9 & 6.9 & 263.0 & 2.8 & 1.6 \\
13 & 239.0 & 7.4 & 14.7 & 594.0 & 2.5 & 3.8 \\
17 & 138.0 & 3.8 & 16.2 & 286.0 & 1.7 & 27.4 \\
21 & 118.0 & 2.8 & 14.3 & 335.0 & 1.6 & 5.7 \\
22 & 214.0 & 6.7 & 14.1 & 300.0 & 1.6 & 19.7 \\
Normal & $10-31$ & $0.7-1.2$ & $3.4-6.3$ & $115-280$ & $2.6-3.8$ & $0.2-0.9$ \\
values & & & & & & \\
\hline
\end{tabular}

*Blood urea nitrogen

***Urine protein/creatinine ratio.

the band with a lower molecular weight described by De Colmenares et al. of 72 $75 \mathrm{kDa}$. However, this band was observed in all sick dogs as well as in $95 \%$ of the healthy dogs (Tab. I). This result did not allow us to affirm or discard this band as an antigenic fraction of the parasite, although its presence in Leishmania negative healthy-dogs possibly might discard this hypothesis. Further studies are needed to clarify the presence of Leishmania antigens in the urine of dogs infected by this microorganism.

Because severe nephropathies usually involve the loss of immunoglobulins in urine $[12,22]$, Western blot was carried out to confirm the excretion of immunoglobulins and the renal lesion. One protein around $70 \mathrm{kDa}$ was recognized by both $\mathrm{IgG}$ and $\mathrm{IgA}$ antibodies in the urine from healthy and sick dogs (Figs. 3 and 4). This band could correspond to a non-specific recognition of albumin, whose molecular weight has been estimated around $69 \mathrm{kDa}$ [11] and can constitute from $40 \%$ to $60 \%$ of the normal urinary proteins in dogs [12].

In the group with leishmaniasis, IgG was detected in 15 dogs (Fig. 4A, Tab. III) whereas $\operatorname{Ig}$ A was found exclusively in 12 of the cases that previously displayed $\mathrm{IgG}$ (Fig. 4B, Tab. III). Using Western blot,
Kohanteb et al. [14] in 1987 performed a study of the urine of patients with leishmaniasis, in which they described the presence of mainly $\mathrm{IgG}$, and to a lesser degree IgA. Similarly to our study, Kohanteb et al. [14] found IgA exclusively in samples in which IgG was also found. In the present study, 13/15 dogs that showed IgG displayed signs of renal failure that would explain the passage of this immunoglobulin across the glomerular filtration barrier. The remaining two dogs showed the highest $\mathrm{U} / \mathrm{C}$ ratios in the dogs with leishmaniasis and without renal failure. Using a specific antibody, IgA was observed in 12 dogs (Fig. 4B, Tab. III). The bands were much less intense and were observed in a lower number of animals than in the case of IgG. It must be taken into account that $\operatorname{IgA}$ is found in a lower concentration in the serum and has a higher molecular weight than IgG [39]. These facts could cause a lower IgA renal excretion although severe glomerular damage is present. Finally, no significant difference was observed in the clinical manifestations of the dogs showing the two types of immunoglobulins in urine compared to the dogs displaying only IgG (Tab. III).

Histopathological findings in the three analyzed dogs (Animals \#2, \#8 and \#20) 
Table V. More significant laboratory abnormalities in the three dogs with leishmaniasis in which the histopathological study was carried out.

\begin{tabular}{lcccccc}
\hline Animal & $\begin{array}{c}* \mathrm{BUN} \\
(\mathrm{mg} / \mathrm{dL})\end{array}$ & $\begin{array}{c}\text { Creatinine } \\
(\mathrm{mg} / \mathrm{dL})\end{array}$ & $\begin{array}{c}\text { Phosphorus } \\
(\mathrm{mg} / \mathrm{dL})\end{array}$ & $\begin{array}{c}\text { Calcium } \\
(\mathrm{mg} / \mathrm{dL})\end{array}$ & $\begin{array}{c}\text { Urine specific } \\
\text { gravity }\end{array}$ & $* * \mathrm{U}$ P/C \\
\hline 2 & 364.0 & 8.1 & 17.1 & 10.4 & 1.012 & 1.1 \\
8 & 178.0 & 9.7 & 28.9 & 4.7 & 1.014 & 0.8 \\
20 & 194.0 & 2.7 & 14.9 & 4.6 & 1.013 & 1.8 \\
\hline
\end{tabular}

*Blood urea nitrogen.

**Urine protein/creatinine ratio.

were in accordance with those described by various authors in cases of leishmaniasis $[8,15,23,26,31,36]$, and corresponded to glomerulonephritis and interstitial nephritis (Fig. 5). Furthermore, the three dogs displayed symptoms (Tab. III) and laboratory signs of renal failure, although their $\mathrm{U} \mathrm{P} / \mathrm{C}$ ratios (Tab. V) were lower than the average $\mathrm{U} P / \mathrm{C}$ ratio in this group (5.4 \pm 6.9$)$. A decreased glomerular filtration rate along with the deterioration of renal function can reduce renal protein losses, resulting in declining $\mathrm{U} \mathrm{P} / \mathrm{C}$ ratios $[4,12]$. The three dogs also excreted $\mathrm{IgG}$ and $\mathrm{IgA}$ in the urine but there were no bands with molecular weights, higher than $110 \mathrm{kDa}$ (Tab. III).

We conclude that the urine electrophoresis from dogs with leishmaniasis displays a mixed proteic pattern with low and high molecular weight proteins $[9,22,28$, 34]. This pattern is in accordance with the glomerular and tubular damage [22, 34], as confirmed by the histopathological results. Proteins with low molecular weights constituted $57.9 \%$, and the rest was composed of medium or high molecular weight proteins. In the control group, the percentage of low molecular weight proteins was only $33.5 \%$. In the Western blot, none of the healthy dogs showed excretion of IgG and/ or $\operatorname{IgA}$, whereas the results from the sick dogs clearly showed that severe glomerular damage existed since the percentage of dogs excreting immunoglobulins was very high (68\% for IgG and 55\% for IgA).

\section{ACKNOWLEDGMENTS}

This work was supported by the "Junta de Extremadura" (grant IPR98A050) and European Social Fund. The authors would like to thank D. Juan Carlos Alonso for his collaboration, and Dra. Beatriz Hernández for the critical comments and English review of the manuscript.

\section{REFERENCES}

[1] Alleman A.R., McSherry L.J., Barbet A.F., Breitschwerdt E.B., Sorenson H.L., Bowie M.V., Belanger M., Recombinant major antigenic protein 2 of Ehrlichia canis: a potential diagnostic tool, J. Clin. Microbiol. 39 (2001) 2494-2499.

[2] Ano H., Makimura S., Harasawa R., Detection of babesia species from infected dog blood by polymerase chain reaction, J. Vet. Med. Sci. 63 (2001) 111-113.

[3] Bazzi C., Petrini C., Rizza V., Arrigo G., Beltrame A., D' amico G., Characterization of proteinuria in primary glomerulonephritides. SDS-PAGE patterns: Clinical significance and prognostic value of low molecular weight ("tubular") proteins, Am. J. Kidney Dis. 29 (1997) 27-35.

[4] Center S.A., Wilkinson E., Smith C.A., Erb H., Lewis R.M., 24-hour urine protein/ creatinine ratio in dogs with protein-losing nephropathies, J. Am. Vet. Med. Assoc. 187 (1985) 820-824.

[5] Ciaramella P., Oliva G., De Luna R., Gradoni L., Ambrosio R., Cortese L., Scalone A., Persechino A., A retrospective clinical study of canine leishmaniasis in 150 dogs naturally infected by Leishmania infantum, Vet. Rec. 141 (1997) 539-543. 
[6] De Colmenares M., Portus M., Riera C., Gallego M., Aisa M.J., Torras S., Muñoz C., Short report: Detection of $72-75-\mathrm{kD}$ and $123-\mathrm{kD}$ fractions of Leishmania antigen in urine of patients with visceral leishmaniasis, Am. J. Trop. Med. Hyg. 52 (1995) 427-428.

[7] Ferrer, L., Leishmaniasis, in: Kirk R.W., Bonagura J.D. (Eds.), Kirk's Current Veterinary Therapy XI, W.B. Saunders Company, Philadelphia, 1992, pp. 266-270.

[8] Font A., Closa J.M., Mokina A., Mascort J., Thrombosis and nephrotic syndrome in a dog with visceral leishmaniasis, J. Small Anim. Pract. 34 (1993) 466-470.

[9] Gleadhill A., Michell R., Clinical measurement of renal function, in: Brainbridge J., Elliot J. (Eds.), Manual of Canine and Feline Nephrology and Urology, British Small Animal Veterinary Association, Cheltenham, 1996, pp. 107-116.

[10] Grauer G.F., CVT Update: Canine glomerulonephritis, in: Bonagura J.D. (Ed.), Kirk's Current Veterinary Therapy XIII, W.B. Saunders Company, Philadelphia, 2000, pp. 851-853.

[11] Grauer G.F., Dibartola S.P., Glomerular disease, in: Ettinger S.J., Feldman E.C. (Eds.), Textbook of Veterinary Internal Medicine, W.B. Saunders Company, Philadelphia, 2000, pp. 1662-1678.

[12] Hurley K.J., Vaden S.L., Proteinuria in dogs and cats: A diagnostic approach, in: Bonagura J.D. (Ed.), Kirk's Current Veterinary Therapy XII, W.B. Saunders Company, Philadelphia, 1995, pp. 937-939.

[13] Iqbal Z., Chaichanasiriwithaya W., Rikihisa Y., Comparison of PCR with other tests for early diagnosis of canine ehrlichiosis. J. Clin. Microbiol. 32 (1994) 1658-1662.

[14] Kohanteb J., Ardehali S.M., Rezai H.R., Detection of Leishmania donovani soluble antigen and antibody in the urine of visceral leishmaniasis patients, Trans. R. Soc. Trop. Med. Hyg. 81 (1987) 578-580.

[15] Koutinas A.F., Kontos V., Kaldrimidou H., Lekkas S., Canine leishmaniasis associated nephropathy: a clinical, clinicopathologic and pathologic study in 14 spontaneous cases with proteinuria, The European Journal of Companion Animal Practice 5 (1999) 31-38.

[16] Kshirsagar B., Wiggins R.C., A map of urine proteins based on one-dimensional SDSpolyacrylamide gel electrophoresis and Western blotting using one microliter of unconcentred urine, Clin. Chim. Acta 158 (1986) 13-22.

[17] Laemmli U.K., Cleavage of structural proteins during the assembly of the head of bacteriophage $\mathrm{T}_{4}$, Nature 227 (1970) 680-685.
[18] Lappin M.R., Protozoal and miscellaneous infections, in: Ettinger S.J., Feldman E.C. (Eds.), Textbook of Veterinary Internal Medicine, W.B. Saunders Company, Philadelphia, 2000, pp. 408-417.

[19] Liste F., Gascón F.M., Allopurinol in the treatment of canine visceral leishmaniasis, Vet. Rec. 137 (1995) 23-24.

[20] Lowry O.H., Rosebrough N.J., Farr A.L., Randall R.J., Protein measurement with the folin phenol reagent, J. Biol. Chem. 193 (1951) 265-275.

[21] Lubega J., Evaluation of urinary proteins by sodium dodecyl sulphate polyacrylamide disc gel electrophoresis and molecular mass analysis, Clin. Chim. Acta 128 (1983) 151167.

[22] Lulich J.P., Osborne C.A., Interpretation of urine protein-creatinine ratios in dogs with glomerular and nonglomerular disorders, Comp. Cont. Educ. Pract. 12 (1990) 59-73.

[23] Marcussen N., Vetner M., Kristensen H.M., Interstitial nephritis and glomerulonephritis in visceral leishmaniasis in a dog, Acta Pathol. Microbiol. Immunol. Scand. Sect. A 97 (1989) 1137-1140.

[24] Martinod S., Brossard M., Moreau Y., Immunity of dogs against Babesia canis, its vector tick Dermacentor reticulatus, and Ixodes ricinus in endemic area, J. Parasitol. 71 (1985) 269-273.

[25] Matsudaira P., Sequence from picomole quantities of proteins electroblotted onto polyvinylidene difluoride membranes, J. Biol. Chem. 262 (1987) 10035-10038.

[26] Nieto C.G., Navarrete I., Habela M.A., Serrano F., Redondo E., Pathological changes in kidneys of dogs with natural Leishmania infection, Vet. Parasitol. 45 (1992) 33-47.

[27] Nieto C.G., García-Alonso M., Requena J.M., Mirón C., Soto M., Alonso C., Navarrete I., Analysis of the humoral immune response to total and recombinant antigens of Leishmania infantum: correlation with disease progression in canine experimental leishmaniasis, Vet. Immunol. Immunopathol. 67 (1999) 117-130.

[28] Osborne C.A., Stevens J.B., Lulich J.P., Ulrich L.K., Bird K.A., Koehler L.A., Swanson L.L., A clinician's analysis of urinalysis, in: Osborne C.A., Finco D.R. (Eds.), Canine and Feline Nephrology and Urology, Williams \& Wilkins, Baltimore, 1995, pp. 136-205.

[29] Outteridge P.M., Veterinary Immunology, Academic Press, London, 1985. 
[30] Piarroux R., Azaiez R., Lossi A.M., Reynier P., Muscatelli F., Gambarelli F., Fontes M., Dumon H., Quilici M., Isolation and characterization of a repetitive DNA sequence from Leishmania infantum: development of a visceral leishmaniasis polymerase chain reaction, Am. J. Trop. Med. Hyg. 49 (1993) 364369.

[31] Poli A., Abramo F., Mancianti F., Nigro M., Pieri, S., Bionda A., Renal involvement in canine leishmaniasis. A light-microscopic, immunohistochemical and electron-microscopic study, Nephron 57 (1991) 444-452.

[32] Ruiz de Gopegui R., Congenital and acquired vascular wall diseases, in: Feldman B.F., Zink1 J.G., Jain N.C. (Eds.), Schalm's Veterinary Hematology, Lippincott Williams \& Wilkins, Philadelphia, 2000, pp. 528-531.

[33] Scherberich J.E., Fischer P., Bigalke A., Stangl P., Wolf G.B., Haimerl M., Schoeppe W., Routine diagnosis with PhastSystem compared to conventional electrophoresis: automated sodium dodecyl sulfate-polyacrylamide gel electrophoresis, silver staining and Western blotting of urinary proteins, Electrophoresis 10 (1989) 58-62.

[34] Schultze A.E., Jensen R.K., Sodium dodecyl sulfate polyacrylamide gel electrophoresis of canine urinary proteins for the analysis and differentiation of tubular and glomerular diseases, Vet. Clin. Pathol. 18 (1989) 93-97.

[35] Scott R.C., Immune-mediated renal disease, in: Kirk R.W., Bonagura J.D. (Eds.), Current
Veterinary Therapy VIII, W.B. Saunders Company, Philadelphia, 1983, pp. 968-975.

[36] Slappendel R.J., Ferrer L., Leishmaniasis, in: Greene C.E. (Ed.), Infectious Diseases of the Dog and Cat, W.B. Saunders Company, Philadelphia, 1998, pp. 450-458.

[37] Squires R., Tacking the problem of proteinuria, In Practice 1 (1994) 30-36.

[38] Temmler L., Nolte I., Evaluation of canine renal disease by SDS-polyacrylamide gel electrophoresis of urine - a follow-up study, Kleintierpraxis 40 (1995) 103-113.

[39] Tizard I.R., Veterinary Immunology. An Introduction, W.B. Saunders Company, Philadelphia, 1996.

[40] Towbin H., Staehelin T., Gordon J., Electrophoretic transfer of proteins from polyacrylamide gels to nitrocellulose sheets procedures and some applications, Proc. Natl. Acad. Sci. USA 76 (1979) 4350-4354.

[41] Verdier J.-M., Dussol B., Dupuy P., Berland Y., Dagorn J-C., Preliminary treatment of urinary proteins improves elctrophoretic analysis and immunodetection, Clin. Chem. 38 (1992) 860-863.

[42] Walker G.R., Feather K.D., Davis P.D., Hines K.K., SuperSignal ${ }^{T M}$ CL-HRP: A new enhanced chemiluminescent substrate for the development of the horseradish peroxide label in Western blotting applications, J. NIH Res. 7 (1995) 76-84. 